\title{
Downhole Pressure Controlled Plunger Gas Lift Research and Application in Block Su75 of Sulige Gas Field
}

\author{
Lina Wang ${ }^{1}$, Gang Cheng ${ }^{2}$, Lianchi Ye ${ }^{3}$, Yongxiang Yang ${ }^{1}$, Xiaofeng $\mathrm{Xu}^{3}$, Jixiang $\mathrm{Ma}^{1}$, Shengli Zhang ${ }^{1}$ and Baohong \\ Zhao $^{4}$ \\ ${ }^{1}$ Institute of oil production engineering in Huabei oilfield, Renqiu, 062552, China. \\ ${ }^{2}$ The third exploit factory of Huabei oilfield company, Hejian, 062450, China. \\ ${ }^{3}$ Project department of Sulige in Huabei oilfield, Wushenqi, 017300, China. \\ ${ }^{4}$ General hospital in Huabei oilfield, Renqiu, 062552, China.
}

\begin{abstract}
Block Su 75 of Sulige gas field belongs to low permeability, low pressure, and low abundance gas reservoir and the number of the wells producing water has been arising year by year, which means the problem which is called as liquid loading has become the main factor influencing the gas well deliverability. Plunger gas lift is one of the important drainage gas recovery technologies to extend the flowing production period of gas wells for it has high automation degree and is easy to manage. While during the field application, its low drainage gas recovery efficiency and bad stimulation effect occurs. So downhole pressure controlled plunger gas lift technology was developed and the field test in Su 75-26X well got better effect. Through practice, downhole pressure controlled plunger gas lift technology has high drainage gas recovery efficiency, for the technology is designed to use reservoirs energy fully, and the plunger is controlled automatically by pressure under the ground rather artificially on the surface. Obviously, downhole pressure controlled plunger gas lift technology has wide popularization and application foreground in Sulige gas field.
\end{abstract}

Keywords-Sulige gas field; liquid loading; drainage gas recovery; plunger; gas lift; field application

\section{OVERVIEW}

Block Su 75, which is located in the west of Sulige gas field and has low structural position and serious gas/water difference, has serious water production situation. The proportion of the gas wells producing water is $86.9 \%$ and the production of gas wells producing water, accounts for $75.5 \%$ of the daily gas production of Block Su 75 . In order to ensure stable production of the block, the drainage gas recovery technology is promoted in the well site in a large scale. Among them, the conventional plunger gas drainage technologies achieved good results in field application, but there are the following shortcomings: 1 . For the gas wells with low gas production and much liquid loading, the plunger often can not effectively run to the wellhead,. 2. The setting depth of plunger is relatively shallow and the fluid which is located in the lower depth can not be excluded, 3 . The ground control systems is difficult to manage. Therefore, to solve the defect of the conventional plunger drainage gas recovery technology, downhole pressure controlled plunger gas lift technology was developed, to reduce ground equipment maintenance workload and improve the drainage efficiency.

\section{Downhole Pressure Controlled Plunger Gas LifT TECHNOLOGY PRINCIPLES}

\section{A. Operating Principle}

Downhole pressure controlled plunger gas lift technology [1] was developed in the case that the drainage efficiency of the conventional plunger gas drainage technologies that was used to weakly natural flow wells or those wells with low gas/liquid ratio, is very low. Pressure controlled plunger and sealed working barrel are designed for the technology [2] [3]. And with those structures the well will be closed when the plunger fall into the working barrel and the well will be open when the pressure builds up to the setting value with the unblocking device controlled by pressure. For the common plunger gas lift, underground gas pressure loss will occur during the process of gas spread and the upward velocity of the plunger is very slow, even can't run to the wellhead. While Downhole pressure controlled plunger gas lift technology not only can solve the problems above and other key issues, but also eliminate the ground flow/shut equipment with time switch usually used in common plunger gas lift. Its cost will be lower than common plunger gas lift and efficiency higher than common plunger gas lift.

The detailed principles are as follows:

(1) The plunger will be locked to the butt joint device and the interspace between the plunger and butt joint device will be sealed when the plunger fall into the butt joint device. And the pressure of the lower portion of the plunger begins to reserve.

(2) The plunger will be unlocked automatically when the difference between the pressure of lower portion of the plunger and the pressure of upper portion of the plunger is greater than the setting value to unlock the plunger. And the plunger will be pushed to move upward rapidly by compressed gas in the annulus and under the plunger and bring the liquid to the ground. At the same time, the drainage gas recovery process ends. 
TABLE I. CORRELATION TABLE OF DOWNHOLE PRESSURE CONTROLLED PLUNGER GAS LIFT TECHNOLOGY AND CONVENTIONAL PLUNGER GAS LIFT TECHNOLOGY

\begin{tabular}{|c|c|c|}
\hline $\begin{array}{l}\text { Compar } \\
\text { ison }\end{array}$ & $\begin{array}{c}\text { Downhole pressure } \\
\text { controlled plunger gas } \\
\text { lift } \\
\end{array}$ & $\begin{array}{l}\text { Conventional plunger } \\
\text { gas lift technology }\end{array}$ \\
\hline Plunger & $\begin{array}{l}\text { Movement controlled } \\
\text { by reservoir pressure } \\
\text { automatically }\end{array}$ & $\begin{array}{l}\text { Movement under the } \\
\text { setting values of surface } \\
\text { control system }\end{array}$ \\
\hline $\begin{array}{l}\text { Butt } \\
\text { joint } \\
\text { device }\end{array}$ & $\begin{array}{l}\text { With choke to set } \\
\text { proration }\end{array}$ & -- \\
\hline $\begin{array}{l}\text { Surface } \\
\text { Device }\end{array}$ & Christmas tree & $\begin{array}{l}\text { Surface control system } \\
\text { and much operation } \\
\text { workload }\end{array}$ \\
\hline Design & $\begin{array}{l}\text { The setting value to } \\
\text { unlock the plunger is } \\
\text { designed according to } \\
\text { reservoir pressure and } \\
\text { its recovery rate }\end{array}$ & $\begin{array}{l}\text { Circulate frequency is set } \\
\text { according to the depth of } \\
\text { liquid loading and } \\
\text { gas/liquid ratio }\end{array}$ \\
\hline
\end{tabular}

\section{B. The Components of Device}

The device mainly includes downhole pressure controlled plunger and fixing device (shown as Figure I) and wellhead arrester (shown as Figure II). With the simple composition, the device is easy to fix.

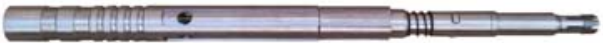

FIGURE I. PRESSURE CONTROLLED PLUNGER AND FIXING DEVICE

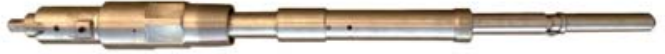

FIGURE II. WELLHEAD ARRESTER

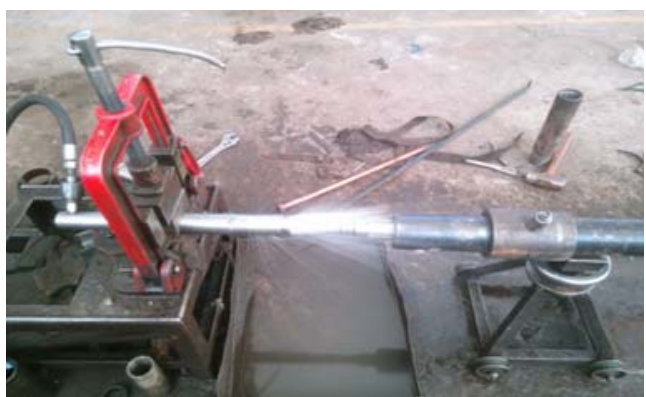

FIGURE III. THE DOCKING, LOCKING AND SEALING TEST OF PLUNGER

\section{Technical Parameters}

The length of the downhole pressure controlled plunger and fixing device is 1.5 meters and the length of the wellhead arrester is 1.0 meter.

\section{Laboratory Test}

The following test for downhole pressure controlled plunger was completed:(1) The docking and locking test of plunger, (2) Pressurization test of butt joint device, (3) Capturing and releasing test of wellhead arrester. Test results show that the plunger can tolerate pressure more than $45 \mathrm{MPa}$ under high temperature and high pressure, plunger can timely dock and lock to butt joint device, and wellhead arrester can capture and release the plunger timely.

\section{FIELD TEST AND BENEFIt ANALysis}

\section{A. Rules of Well Selection}

1. Low production wells with liquid loading and a certain energy;

2. The internal diameter of the pipe string above clamping device keeps same as the drift diameter of wellhead Christmas tree;

3. The depth should be less than 3500 meters and the deviation should be less than 75 degrees.

\section{B. Field Experiments}

According to the rules of well selection of downhole pressure controlled plunger drainage gas recovery technology, the well Su 75-26X is selected to carry out the field application test. The field test is shown in Figure V. Before the application test, the production situation of well Su $75-26 \mathrm{X}$ is shown in table II.

TABLE II. THE PRODUCTION SITUATION OF WELL SU 75-26X BEFORE THE APPLICATION TEST

\begin{tabular}{|c|c|c|c|c|c|c|}
\hline Well & $\begin{array}{c}\text { Gas } \\
\text { Rate } \\
(\mathrm{m} 3 / \mathrm{d} \\
\text { ) }\end{array}$ & $\begin{array}{c}\text { Tubing } \\
\text { pressur } \\
\text { e } \\
\text { (MPa) }\end{array}$ & $\begin{array}{c}\text { Casing } \\
\text { pressur } \\
\text { e } \\
(\mathrm{MPa})\end{array}$ & $\begin{array}{l}\text { The } \\
\text { dept } \\
\text { h of } \\
\text { bean } \\
\text { chok } \\
\text { e (m) }\end{array}$ & $\begin{array}{c}\text { Deflectio } \\
\text { n point } \\
\text { (m) }\end{array}$ & $\begin{array}{c}\text { Maximu } \\
\text { m } \\
\text { deviation } \\
\left(^{\circ}\right)\end{array}$ \\
\hline $\begin{array}{l}\mathrm{Su} \\
75-26 \\
\mathrm{X}\end{array}$ & $\begin{array}{l}0.552 \\
2\end{array}$ & 3.52 & 13.97 & 1597 & 897 & 17 \\
\hline
\end{tabular}

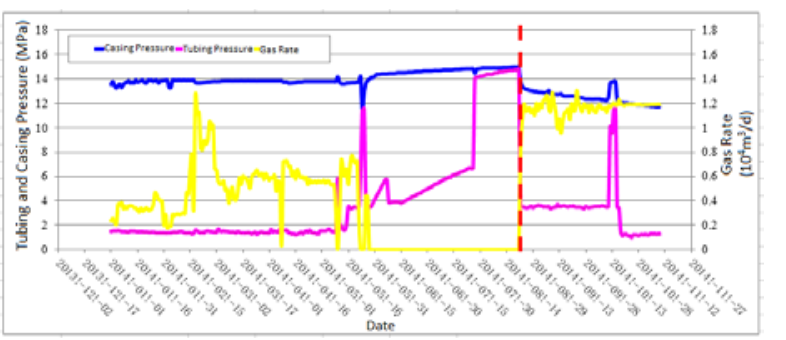

FIGURE IV. PRODUCTION CURVES OF WELL SU 75-58-26X

Before the application test, the gas rate of well Su 75-26X is $0.5522 \times 10^{4} \mathrm{~m}^{3} / \mathrm{d}$. In August 21th, 2014, the construction of downhole pressure controlled plunger drainage gas recovery technology was completed. After the construction, the depth of the bean choke is 2970 meters, the tubing pressure is $3.41 \mathrm{MPa}$ and the casing pressure is $12.34 \mathrm{MPa}$. And after the construction, the gas rate of well Su75-26X is $1.1427 \times 10^{4} \mathrm{~m}^{3} / \mathrm{d}$, which means the increasing production is $0.5872 \times 10^{4} \mathrm{~m}^{3} / \mathrm{d}$. The detailed parameters are shown in Table III. 
TABLE III. THE CONSTRUCTION EFFECT OF WELL SU 75-26X

\begin{tabular}{|c|c|c|c|c|c|c|c|c|c|c|c|c|}
\hline \multirow[b]{2}{*}{ Well } & \multirow[b]{2}{*}{ Date } & \multicolumn{5}{|c|}{ Before the construction } & \multicolumn{5}{|c|}{ After the construction } & \multirow[b]{2}{*}{$\begin{array}{c}\text { Increasing } \\
\text { production } \\
\quad\left(\mathrm{m}^{3} / \mathrm{d}\right)\end{array}$} \\
\hline & & $\begin{array}{c}\text { ID of } \\
\text { gas } \\
\text { choke } \\
(\mathrm{mm})\end{array}$ & $\begin{array}{c}\text { The } \\
\text { depth } \\
\text { of bean } \\
\text { choke } \\
\text { (m) }\end{array}$ & $\begin{array}{c}\text { Gas } \\
\text { Rate } \\
\left(\mathrm{m}^{3} / \mathrm{d}\right)\end{array}$ & $\begin{array}{c}\text { Tubing } \\
\text { pressure } \\
\text { (MPa) }\end{array}$ & $\begin{array}{c}\text { Casing } \\
\text { pressure } \\
\text { (MPa) }\end{array}$ & $\begin{array}{c}\text { ID of } \\
\text { gas } \\
\text { choke } \\
(\mathrm{mm})\end{array}$ & $\begin{array}{c}\text { The } \\
\text { depth } \\
\text { of bean } \\
\text { choke } \\
(m)\end{array}$ & $\begin{array}{c}\text { Gas } \\
\text { Rate } \\
\left(\mathrm{m}^{3} / \mathrm{d}\right)\end{array}$ & $\begin{array}{c}\text { Tubing } \\
\text { pressure } \\
\text { (MPa) }\end{array}$ & $\begin{array}{c}\text { Casing } \\
\text { pressure } \\
\text { (MPa) }\end{array}$ & \\
\hline $\begin{array}{l}\text { Su } \\
75-26 X\end{array}$ & 2014.8.21 & 2 & 1591 & 0.5522 & 3.52 & 13.79 & 2.6 & 2970 & 1.1427 & 3.5 & 12.69 & 0.5872 \\
\hline
\end{tabular}

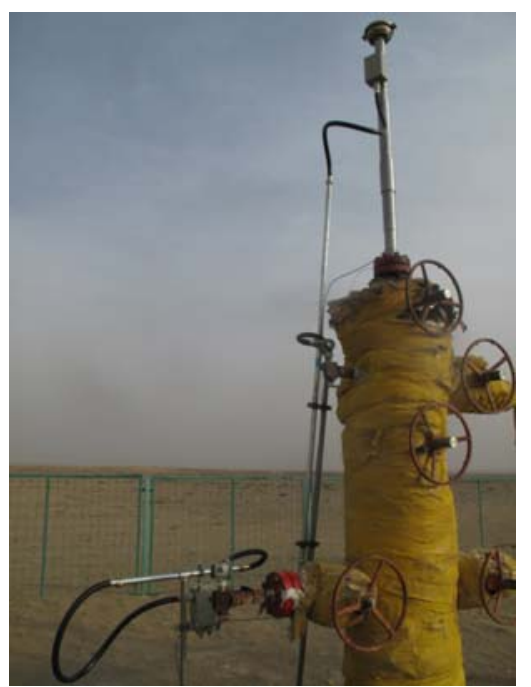

FIGURE V. THE FIELD TEST OF DOWNHOLE PRESSURE CONTROLLED PLUNGER

\section{Benefit analysis}

\section{1) Economic benefit:}

The daily increasing production of well $\mathrm{Su} 75-26 \mathrm{X}$ is $0.5872 \times 10^{4} \mathrm{~m}^{3} / \mathrm{d}$ and the total one is $76.3 \times 10^{4} \mathrm{~m}^{3} / \mathrm{d}$ during the construction period. The price of natural gas is 1257 Yuan for per thousand cubic meters and the economic benefit should be 959.5 thousand Yuan.

\section{2) Social benefit:}

The research and development of downhole pressure controlled plunger drainage gas recovery technology is another innovation in the process of drainage gas recovery, which fully utilizes the ground lamination energy, has high liquid carrying efficiency and guarantees the plunger going up and down freely in the wellbore. The technology is of great significance to the late development of Sulige gas field.

\section{CONCLUSIONS}

1. According to the shortcomings of the conventional plunger gas lift technology in field application, the downhole pressure controlled plunger gas lift technique was developed and used in the field test of well Su 75-26X. The technology can improve the drainage gas recovery efficiency and gas rate of the weakly natural flow wells or those wells with low gas/liquid ratio. At the same time, the technology will have wide popularization and application foreground in Sulige gas field for it can reduce maintenance workload without ground equipment.

2. The downhole pressure control plunger gas lift technology is fit for the early water breakthrough stage of gas wells in Sulige gas field, prolonging the flowing production period. And the technology has an important guiding significance to the stable production of Sulige gas field.

\section{REFERENCE}

[1] Li Shilun, et al. Gas Engineering[M]. Beijing: Petroleum Industry Press, 2008:231-235.

[2] Wang Qisheng, Liao Ruiquan. The Study of Plunger Motion in Plunger Gas lift[J]. Journal of Basic Science and Engineering, 2000,8(1):89-95.

[3] He Shunli, Wu Zhijun. Establishment of Dynamic Model for Plunger Gas Lift[J]. Acta Petrolei Sinica,2005,26(4):88-92. 